\title{
Wyzwania integracji źródeł kartograficznych i tekstowych na przykładzie Warszawy w XVIII w.
}

\author{
Marta Kuc-Czerep \\ https://orcid.org/0000-0003-0049-834X \\ Instytut Historii im. Tadeusza Manteuffla Polskiej Akademii Nauk
}

\section{Katarzyna Słomska}

https://orcid.org/0000-0003-3669-0018

Instytut Historii im. Tadeusza Manteuffla Polskiej Akademii Nauk

Zarys treści: Systemy informacji geograficznej coraz częściej wykorzystywane są przez historyków zajmujących się problematyką miejską. Celem niniejszego artykułu jest przedstawienie możliwości zastosowania tych narzędzi do rozpoznania rozwoju przestrzennego Warszawy w XVIII w. Omówione zostaną kwestie dotyczące integracji danych ze źródeł kartograficznych i pisanych, m.in. kalibracja dawnych map, ewidencja działek miejskich i wyznaczenie między nimi granic. Zaprezentowana zostanie też przykładowa wizualizacja danych źródłowych.

Słowa kluczowe: topografia historyczna, historia miast, mapa katastralna, przestrzeń miejska, Warszawa

\section{Wprowadzenie}

HGIS w znacznym stopniu ułatwia badanie przestrzeni miejskich oraz zachodzących tam procesów i relacji między mieszkańcami. Może być także z powodzeniem wykorzystywany w pracach porównawczych. Wskazanie jednolitego bądź dominującego podejścia w badaniach z wykorzystaniem tego narzędzia jest jednak trudne ze względu na wielość celów, jakie stawiają sobie naukowcy. Część z publikowanych $\mathrm{w}$ internecie projektów ma służyć udostępnieniu wielotematycznych danych historycznych na współczesnym podkładzie ${ }^{1}$. W niektórych przypadkach portale rozbudowywane są o możliwość

Serwisy Mapowe, „Miasto Stołeczne Warszawa” (www.mapa.um.warszawa. pl, dostęp: 30 maja 2019).
Abstract: Geographic information systems are increasingly used by historians dealing with urban studies. The aim of our paper is to present the possibilities of using these tools to analyse the spatial development of Warsaw in the $18^{\text {th }}$ century. Issues related to the integration of data derived from cartographic and written sources will be discussed, including calibration of old maps, records of city plots and drawing up of borders between them. An example visualization of source data will be presented.

Keywords: historical topography, history of towns, cadastral map, urban space, Warsaw

wykorzystania w charakterze podkładu georeferowanych map dawnych ${ }^{2}$. Innym rozwiązaniem jest połączenie mapy dawnej i źródeł historycznych (np. projekty DECIMA - The Digitally Encoded Census Information and Mapping Archive we Florecji ${ }^{3}$ czy Els „Quarterons Garriga i Roca” w Barcelonie ${ }^{4}$ ). Niestety, nie wszystkie opracowania przygotowywane za pomocą narzędzi GIS udostępniono w formie cyfrowej ${ }^{5}$.

\footnotetext{
"Layers of London" (www.layersoflondon.org, dostęp: 30 maja 2019).

3 "DECIMA" - The Digitally Encoded Census Information and Mapping Archive (www.decima-map.net, dostęp: 30 maja 2019).

4 Els ,Quarterons Garriga i Roca". Barcelona, darrera mirada. Una ciutat de mitjan segle XIX a punt de canviar per sempre, „Ajuntament de Barcelona” (www.darreramirada.ajuntament.barcelona.cat, dostęp: 30 maja 2019).

${ }^{5} \mathrm{~K}$. Lelo, $A$ GIS approach to urban history. Rome in the $18^{\text {th }}$ century, ,ISPRS International Journal of Geo-Information", 3 (4), 2014, s. 1293-1316.
} 
Jednym z najdłużej trwających projektów dotyczących ośrodków miejskich jest zainicjowana w 1955 r. seria „European Historic Towns Atlas". Kolejne publikowane w niej tomy muszą być opracowane zgodnie z wytycznymi Międzynarodowej Komisji Historii Miast (International Commission for the History of Towns) ${ }^{6}$. Każdy zeszyt zawiera obligatoryjny zestaw map, w skład którego wchodzi reprodukcja pierwszego w pełni kartometrycznego planu miasta. W 2014 r. komisja przyjęła oficjalną strategię cyfrową (digital strategy) ${ }^{7}$. Realizują ją poszczególne zespoły atlasowe przygotowujące kolejne zeszyty zarówno w wersji papierowej, jak i cyfrowej. Nowe rozwiązania technologiczne umożliwiają pełniejsze wykorzystanie źródeł pisanych i kartograficznych. Za przykład można podać prace zespołu pracującego nad wydaniem nowego zeszytu Torunia ${ }^{8}$.

Projekt mający na celu prowadzenie badań z zakresu topografii i socjotopografii Warszawy realizowany jest od $2018 \mathrm{r}$. w Instytucie Historii PAN. W pierwszym etapie działania koncentrują się na wypracowaniu metody badawczej, która będzie służyć rekonstrukcji przestrzeni miejskiej Warszawy w XVIII stuleciu z uwzględnieniem specyfiki rozwoju tego ośrodka. Przygotowywana jest także baza danych gromadząca informacje ze źródeł miejskich. Wszystkie te działania pozwolą opracować mapę rekonstrukcyjną Warszawy w XVIII w., a następnie przeprowadzić analizę zjawisk demograficznych zachodzących w mieście w ciągu całego stulecia. Tak przygotowana mapa będzie punktem wyjścia do rozpoczęcia badań nad okresem wcześniejszym (XIV-XVII w.) oraz późniejszym (XIX i XX w.). Przeprowadzenie tych badań jest niezbędne do przygotowania pierwszego

\footnotetext{
${ }^{6}$ R. Czaja, Historical Atlas of Polish Towns - between source edition and the cartographic presentation of research on the history of towns, „Studia Geohistorica", 6, 2018, s. 80-90.

E. Chodějovská, S. Gearty, D. Stracke, The „digital turn" of the European Historic Towns Atlas: comparing solutions for digital atlas production and online presentation, „Città e Storia”, 10 (1), 2015, s. 89-121.

${ }^{8}$ Tamże, s. 86-87.
}

zeszytu mazowieckiego tomu w serii „Atlas Historyczny Miast Polskich”. Wobec zaawansowanych prac nad ośrodkami miejskimi w sąsiednich województwach dawnej Rzeczypospolitej będzie to wypełnienie istotnej luki w badaniach?

\section{Badania nad Warszawą w epoce nowożytnej}

Badania nad przestrzenią miejską i stosunkami ludnościowymi obejmują przede wszystkim średniowiecze, a jako ich przykłady można przywołać prace dotyczące Poznania, Elbląga, Wrocławia, Sieradza i Warty ${ }^{10}$. W mniejszym stopniu dotyczą natomiast okresu nowożytnego: Toruniowi i jego przedmieściom przyglądał się Krzysztof Mikulski ${ }^{11}$, a osiemnastowieczny i dziewiętnastowieczny Kraków badał z wykorzystaniem narzędzi GIS Konrad Wnęk ${ }^{12}$. Przestrzeń i ludność Warszawy w XVIII w. wciąż pozostają na tym tle ważnym postulatem. Problematyka ta budzi zainteresowanie młodych badaczy, którzy w pracach doktorskich pochylali się nad topografią Warszawy w XVI i XVII w. ${ }^{13} \mathrm{~W}$ pewnym stopniu zainicjowat je Samuel Szymkiewicz, autor wydanej w 1959 r. pracy Warszawa na przetomie XVIII i XIX w. w świetle pomiarów i spisów ${ }^{14}$. Analizując spis mieszkańców miasta z 1792 r., odwoływał się również do

\footnotetext{
${ }^{9}$ H. Rutkowski, Dawna kartografia Warszawy, „Rocznik Warszawski”, 32, 2004, s. 95-98.

${ }^{10} \mathrm{~J}$. Wiesiołowski, Socjotopografia późnośredniowiecznego Poznania, Poznań 1997; R. Czaja, Socjotopografia miasta Elblaga w średniowieczu, Toruń 1992; M. Goliński, Socjotopografia późnośredniowiecznego Wrocławia (przestrzeń - podatnicy - rzemiosto), Wrocław 1997; U. Sowina, Sieradz. Układ przestrzenny ispoteczeństwo miasta w XV-XVI w. Warszawa-Sieradz 1991; A. Bartoszewicz, Warta - społeczeństwo miasta w II połowie XV i na początku XVI wieku, Warszawa 1997.

${ }^{11}$ K. Mikulski, Przestrzeń i społeczeństwo Torunia od końca XIV do początku XVIII wieku, Toruń 1999.

${ }^{12}$ K. Wnęk, Własność nieruchomości w Krakowie w potowie XIX w. Studia nad stałym katastrem galicyjskim, Kraków 2011.

${ }^{13}$ K. Mrozowski, Przestrzeń i obywatele Starej Warszawy od schytku XV w. do 1569 roku, Warszawa 2017, mps pracy doktorskiej, Biblioteka Instytutu Historii Uniwersytetu Warszawskiego; K. Zwierz, Miasto sejmowe Warszawa - polityczne uwarunkowania rozwoju miasta 1570-1655, Warszawa 2019, mps pracy doktorskiej, Biblioteka Instytutu Historii im. Tadeusza Manteuffla Polskiej Akademii Nauk.

${ }^{14}$ S. Szymkiewicz, Warszawa na przefomie XVIII i XIX w. w świetle pomiarów i spisów, Warszawa 1959.
} 
innych tego typu źródeł powstałych w latach dziewięćdziesiątych XVIII w. Hanna Szwankowska, posiłkując się rewizją miasta z 1790 r., podjęła próbę ukazania jego zabudowy z podziałem na murowana i drewnianą ${ }^{15}$. Spośród dostępnych źródeł pisanych, w najmniejszym stopniu wykorzystywany był w badaniach spis ludności luterańskiej z 1791 r. ${ }^{16}$ Ważne ustalenia na temat struktury własności w mieście zawarte są w książce Teresy Zielińskiej poświęconej szlacheckim właścicielom nieruchomości w miastach $\mathrm{w}$ XVIII w. ${ }^{17}$ Ukazało się też wiele publikacji omawiających kartografię Warszawy, m.in. Atlas historyczny Warszawy, zawierający opis wybranych planów miasta i jego okolic od drugiej połowy XVIII w. do drugiej wojny światowej ${ }^{18}$.

Wybór XVIII w. w badaniu Warszawy jest w pełni uzasadniony. Należy podkreślić, że jest to jeden z najważniejszych etapów rozwoju miasta, które w drugiej połowie tego stulecia $\mathrm{z}$ małego ośrodka zniszczonego wskutek działań wojennych i epidemii stało się najważniejszym miastem pierwszej Rzeczypospolitej-centrum życia politycznego, siedzibą władcy i jego urzędników, miejscem obrad sejmów, jak również najważniejszym ośrodkiem rzemiosła i handlu na ziemiach polskich. $\mathrm{Na}$ tle innych ośrodków miejskich Warszawa wyróżniała się ponadto tempem wzrostu demograficznego ${ }^{19}$. Według szacunkowych danych w dobie Sejmu Wielkiego liczyła ponad 100 tys. mieszkańców ${ }^{20}$.

\footnotetext{
${ }^{15}$ H. Szwankowska, Drewniana zabudowa mieszkaniowa Warszawy Oświecenia, w: Warszawa XVIII wieku, z. 1: Studia warszawskie, red. J. Kowecki, Warszawa 1971, s. 191-228.

${ }^{16}$ W. Kriegseisen, Ewangelicy warszawscy w dobie Sejmu Czteroletniego. Miejsca zamieszkania, zawody, zamożność, w: Obecni... Karty z dziejów ewangelików warszawskich. Materiały z sesji popularnonaukowej, [oprac. B. Rogalska, J. Wiśniewska], Warszawa 1992, s. 28-34.

${ }^{17}$ T. Zielińska, Szlacheccy właściciele nieruchomości w miastach XVIII w. Warszawa-Łódź 1987.

${ }^{18}$ Atlas historyczny Warszawy. Wybrane źródła kartograficzne, red. A. Jankiewicz, Warszawa 1999.

${ }^{19}$ Por. B. Grochulska, Warszawa na mapie Polski stanisławowskiej. Podstawy gospodarcze rozwoju miasta, Warszawa 1786.

${ }^{20}$ Taż, Problem wzrostu ludności Warszawy w drugiej połowie XVIII wieku,
} „Rocznik Warszawski”, 7, 1966, s. 182-187.
Z dotychczasowych badań wynika, że XVIII w. to w dziejach Warszawy okres dynamicznego rozwoju przestrzennego i urbanistycznego - rozrastała się wówczas na północ, południe i zachód $^{21}$. Proces regulacji miasta zainicjował w 1715 r. król August II, powołując Saski Urząd Budowlany (Das Königliche Bauamt in Warschau), który był filią drezdeńskiego Generalbaudirektion. W miejsce chaotycznej i spontanicznej rozbudowy wprowadzono planowe rozwiązania urbanistyczne ${ }^{22}$. Efektem działalności wybitnych architektów królewskich była realizacja dużego projektu urbanistycznego określanego jako Oś Saska. Centralnym punktem tego założenia był pałac królewski z przylegającym ogrodem. Inwestycja wpłynęła na powstanie nowego układu ulic na zachód od Krakowskiego Przedmieścia ${ }^{23}$. W kierunku południowym na gruntach wsi Ujazdów wytyczono szeroką aleję nazwaną Drogą Kalwaryjską, wzdłuż której wzniesiono 28 kaplic, a w pobliżu Zamku Ujazdowskiego - kaplicę Grobu Chrystusa. Rozwój tej części miasta kontynuowany był za panowania króla Stanisława Augusta. Przeprowadzono wówczas nowoczesne rozplanowanie dzielnicy południowej, a w wyniku połączenia Zamku Ujazdowskiego z ulicami i placami położonymi na zachód od niego powstał charakterystyczny układ gwiaździsty, tzw. Oś Stanisławowska ${ }^{24}$.

Należy podkreślić, że do 1791 r. Warszawa nie stanowiła jednolitego organizmu miejskiego. Obok gruntów podlegających jurysdykcji magistratu Starej i Nowej

\footnotetext{
${ }^{21}$ Por. D. Kosacka, Pótnocna Warszawa w XVIII wieku, Warszawa 1970.

${ }^{22}$ Szerzej zob. W. Hentschel, Die sächsische Baukunst des 18. Jahrhunderts in Polen, Berlin 1967; J. Sito, „Od czasów Augustów szczególniej liczba niemieckich artystów i rzemieślników w Warszawie wzrosła..." . O roli nacji niemieckiej w przedsięwzięciach budowlano-artystycznych Warszawy okresu saskiego, w: Kultura artystyczna Warszawy XVII-XX w. red. A. Pieńkos, Z. Michalczyk, M. Wardzyński, Warszawa 2010, s. 159-171.

${ }^{23}$ Szerzej zob. D. Kłosek-Kozłowska, 0 wartościach przestrzennych Osi Saskiej Warszawy, „Kwartalnik Architektury i Urbanistyki”, 62 (3), 2017, s. 5-42.

${ }^{24}$ M. Boguska i in., Warszawa w latach 1526-1795, w: Dzieje Warszawy, t. 2, red. S. Kieniewicz, Warszawa 1984, s. 300.
} 
Warszawy powstawały magnacko-szlacheckie i kościelne jurydyki. Zajmowany przez nie obszar był wielokrotnie większy od terytorium stanowiącego własność miejską. Ich powstanie przyczyniło się do zagospodarowania przestrzennego dużych obszarów przylegających do gruntów miejskich i wpłynęło na wyznaczenie kierunków dalszej ekspansji Warszawy. Do końca XVII w. powstało osiemnaście jurydyk, a w ciągu XVIII w. - kolejnych sześć ${ }^{25}$. Przykładem dobrze zaplanowanej jurydyki było Bielino, założone w 1757 r. przez marszałka wielkiego koronnego Franciszka Bielińskiego. Jako jedyna miała ona dokładnie przemyślaną sieć ulic i placów, wśród których centralną pozycję zajmowała ulica Bielińska, przemianowana następnie na Marszałkowską ${ }^{26}$.

Każda z dzielnic dynamicznie rozwijającego się miasta miała określony profil społeczny, co do pewnego stopnia znalazło odzwierciedlenie w typie zabudowy. $\mathrm{Na}$ podkreślenie zasługuje fakt, że w drugiej połowie XVIII w. nastąpiła powolna degradacja Starego Miasta, które przestało pełnić funkcję centralnej dzielnicy. Stało się ono dzielnicą zamieszkaną głównie przez rzemieślników, a eleganckim i bogatym centrum miasta zostało Krakowskie Przedmieście, gdzie znajdowały się kamienice należące do zamożnego mieszczaństwa ${ }^{27}$.

Ważnym momentem w rozwoju przestrzennym Warszawy było usypanie w latach 1770-1772 wałów o charakterze kontrolno-sanitarnym, określanych od nazwiska marszałka wielkiego koronnego Stanisława Lubomirskiego wałami Lubomirskiego (ryc. 1). Zastąpiły one dotychczasowy wał Zygmuntowski, usypany w latach 16211624. Wytyczony zasięg miasta przetrwał ( $\mathrm{z}$ małymi przesunięciami $\mathrm{z}$ pierwszej połowy XIX w.) do 1916 r., gdy w jego

\footnotetext{
${ }^{25}$ Tamże, s. 300-302.

${ }^{26}$ S. Herbst, Ulica Marszałkowska, Warszawa 1949.

${ }^{27}$ W. Szaniawska, Zmiany w rozplanowaniu i zabudowie Krakowskiego Przedmieścia do 1733 r., „Biuletyn Historii Sztuki”, 29, 1967, s. 285-315.
}

granice włączono obszary rozwijające się poza wałami ${ }^{28}$.

Z punktu widzenia badań nad topografią Warszawy w XVIII w. istotne znaczenie miało również urzędowe zatwierdzenie nazw ulic przez Komisję Dobrego Porządku w $1770 \mathrm{r}^{29}$, a następnie nadanie w 1784 r. stałej numeracji poszczególnym parcelom na terenie miasta ${ }^{30}$.

\section{Podstawa źródłowa}

Christopher D. Lloyd, Ian N. Gregory, Ian G. Shuttleworth i Keith D. Lilley ${ }^{31}$ zaproponowali schemat klasyfikacji źródeł dotyczących historycznych przestrzeni miejskich:

1. prospekcja terenowa (archeological survey);

2. mapa obiektów, które przetrwały w niezmienionej formie do czasów współczesnych (surviving landscape features mapped by survey);

3. dawna kartografia (historical cartography);

4. administracyjne źródła tekstowe o odniesieniu przestrzennym (administrativeltextual source data that can be spatially referenced to points or areas).

Do tej pory w projekcie wykorzystywano dane spisowe (4) oraz dawną kartografię (3). Dzięki porównaniu map dawnych i współczesnych danych przestrzennych (Ewidencji Gruntów i Budynków (EGiB) oraz Bazy Danych Obiektów Topograficznych) w analizach brane są też pod uwagę niezmienione części krajobrazu miejskiego - głównie kościoły. Połączenie danych tekstowych z mapą pozwala na kompleksowe badanie przestrzeni miejskiej w przeszłości.

\footnotetext{
${ }^{28}$ A. Berdecka, I. Turnau, Życie codzienne w Warszawie okresu Oświecenia, Warszawa 1969, s. 238-239.

${ }_{29}$ Por. A. Wyrobisz, Nazwy placów, ulic i dzielnic w miastach polskich: nośniki informacji - źródła historyczne - zabytki kultury, „Przegląd Historyczny”, 90, 1999, s. 511-523.

${ }^{30}$ S. Szymkiewicz, Warszawa, s. 17.

${ }^{31}$ C.D. Lloyd i in., Exploring change in urban areas using GIS. Data sources, linkages and problems, „Annals of GIS”, 18 (1), 2012, s. 71-80.
} 


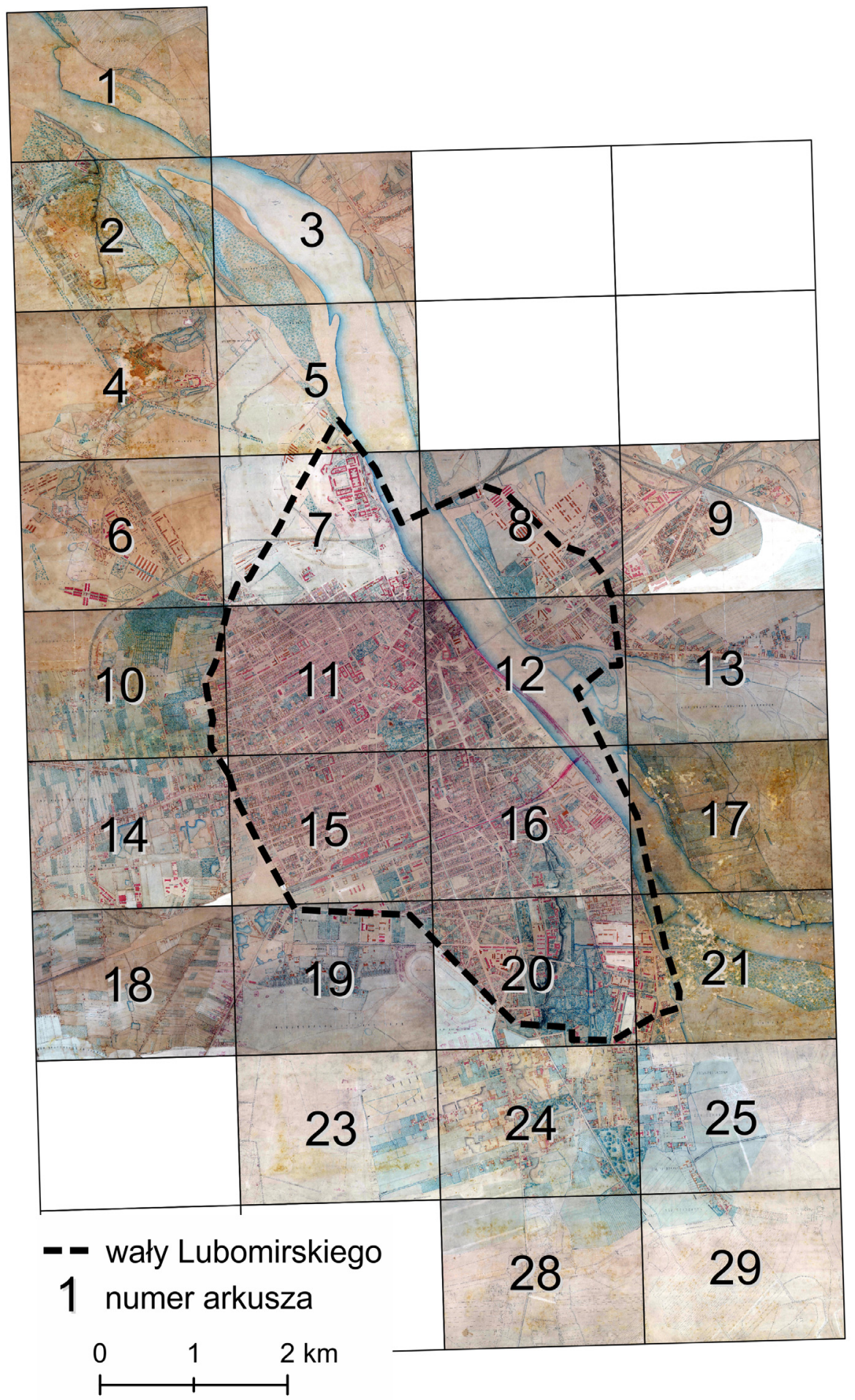

Ryc. 1. Przebieg wałów Lubomirskiego a zasięg planu Lindleyów w skali 1:2500.

Źródło: oprac. własne na podkładzie planu Lindleyów w skali 1:2500 (zmniejszenie 1:32) 


\section{1. Źródła pisane}

Zachowany zespół źródeł miejskich pozwala na prowadzenie szeroko zakrojonych badań nad topografią i socjotopografią Warszawy w XVIII w. Archiwalia te dotyczą m.in. pracy Komisji Brukowej (działającej w latach 1740-1794), Komisji Dobrego Porządku (1765-1791) i Komisji Porządkowej Cywilno-Wojskowej (powołanej w 1791 r.). Istotne dane z zakresu omawianej problematyki zawierają też archiwa Starej i Nowej Warszawy (protokoły publicznych sesji magistratu, testamenty i inwentarze mieszczańskie) oraz księgi metrykalne warszawskich parafii.

Podstawowe typy źródeł, które zostały wykorzystane w pracach zespołu, to spisy mieszkańców miasta, rewizje nieruchomości i spisy podatkowe z drugiej połowy XVIII w. Największe znaczenie ma powstała w 1784 r. rękopiśmienna taryfa domów, która objęła lewobrzeżną część Warszawy (bez Pragi) ${ }^{32}$. Jest to o tyle istotne źródło, że po raz pierwszy wymieniono w nim numery każdej znajdującej się na terenie miasta posesji. Poza tym zawiera ono następujące informacje: nazwy ulic, nazwiska właścicieli nieruchomości, typ zabudowy, długość zabudowy w łokciach, liczbę pięter, okien i sklepów oraz wysokość czynszu płaconego miastu. Każdy rejestr mieszkańców i nieruchomości, który powstał później, uwzględniał wprowadzoną wówczas numerację porządkową.

Pierwszy spis warszawskich parcel i znajdujących się na nich zabudowań (bez Pragi) sporządzony został w $1790 \mathrm{r}$. na podstawie rozporządzenia magistratu z 11 marca $1790 \mathrm{r}^{33}$ Ułożony zgodnie z numeracją posesji wykaz zawiera precyzyjne dane na temat rodzaju budowli, nazwisk właścicieli budowli i gruntów oraz sąsiadów, a także opisy i wymiary posesji oraz spisy budynków na działce wraz z ich wymiarami, liczbą pięter i okien. Poza kartami

\footnotetext{
${ }^{32}$ Archiwum Główne Akt Dawnych [dalej: AGAD], Warszawa - Ekonomiczne [dalej: WE], sygn. 29a.

${ }^{33}$ S. Szymkiewicz, Warszawa, s. 18-20.
}

wypełnionymi zgodnie ze schematem znajdują się tam takie, na których przedstawiona została zabudowa konkretnych kwartałów miasta czy rozmieszczenie poszczególnych budynków na konkretnej działce, a także opisy wnętrz kamienic.

Kolejne źródło to Protokót rewizji miasta, sporządzony przez magistrat w 1792 r. na podstawie uniwersału marszałka wielkiego koronnego Jerzego Mniszcha i Komisji Policji Obojga Narodów ${ }^{34}$. Opisy nieruchomości zawierają nazwę ulicy, numer posesji, dane właściciela oraz podstawowe dane dotyczące współmałżonków i dzieci, a także liczbę kobiet i mężczyzn w danym gospodarstwie. Wymieniono w nich również inne osoby zamieszkujące na terenie nieruchomości (lokatorów), podając ich imiona i nazwiska, zawody, skład rodziny oraz liczbę kobiet i mężczyzn w gospodarstwie. Mieszkańcy miasta podzieleni zostali w spisie na posesjonatów i nieposesjonatów (właścicieli i lokatorów) oraz osoby wykonujące określony zawód i bez zawodu. Wprowadzono także podział według przynależności stanowej: na duchowieństwo, szlachtę i mieszczaństwo oraz według religii - na chrześcijan i żydów. Według tego samego schematu, tj. numerów posesji, przygotowane zostały w $1791 \mathrm{r}$. rejestr ludności wyznania ewangelicko-augsburskiego i spis mieszkańców parafii św. Krzyżza ${ }^{35}$.

Dane zawarte w powyższych źródłach będą punktem odniesienia do analizy tego typu materiałów archiwalnych z pierwszej połowy XVIII w.

\section{2. Źródła kartograficzne}

Podstawę kartograficzną projektu stanowią mapy Warszawy opracowane między XVIII aXX w., jak również zachowane w archiwach plany ukazujące zabudowę określonych obszarów miasta i konkretnych działek.

\footnotetext{
${ }^{34}$ Tamże, s. 30.

${ }^{35}$ Por. Rejestr warszawskiej ludności wyznania ewangelicko-augsburskiego z 1791 roku, oprac. indeksu osób M. Kubaś, Warszawa 1996; C. Kuklo, Rodzina w osiemnastowiecznej Warszawie, Białystok 1991.
} 
Spośród planów miasta na uwagę zasługują te, które będą szczególnie pomocne w przygotowaniu mapy wektorowej Warszawy w XVIII w. Jako pierwszy chronologicznie należy wymienić plan przygotowany w 1762 r. przez francuskiego inżyniera, geometrę i architekta Pierre'a Ricauda de Tirregaille'a - pierwszy, którego przygotowanie poprzedzono przeprowadzeniem pomiarów Warszawy ${ }^{36}$. Zlecił je marszałek wielki koronny Franciszek Bieliński, kierujący w latach 1742-1766 Komisją Brukową. Plan przygotowany został w dwóch wersjach - rękopiśmiennej w skali 1:1100 oraz miedziorytowej w skali 1:6750. Ukazano na nim lewobrzeżną część miasta, tereny Starej i Nowej Warszawy, ich przedmieścia oraz istniejące wówczas jurydyki, podając też nazwy ulic oraz numery części działek.

Kolejny plan to Delineacja Antoniego Hiża i Hieronima Jędrzejowskiego, sporządzona w $1771 \mathrm{r}$. na jedenastu arkuszach szczegółowych w skali ok. 1:2200 oraz jednym arkuszu zbiorczym w skali ok. 1:7940 ${ }^{37}$. Przedstawiono na nim lewobrzeżną Warszawę z zabudową, siecią uliczną, zielenią i przebiegiem publicznych kanałów ściekowych oraz przebiegiem wałów Lubomirskiego (por. ryc. 1). Odmiennymi barwami oznaczona została zabudowa murowana i drewniana.

Numerację części działek podano również na planie z 1808 r., przygotowanym przez Johanna Georga Lehmanna i rytownika Josepha Bacha ${ }^{38}$. Skala ok. 1:11700 pozwoliła na szczegółową prezentację zabudowy (z zaznaczeniem jej rodzajów) i zapisanie nazw ulic. Należy też wspomnieć o planie oficerów Korpusu Inżynierów Wojskowych w skali 1:4800, na którym również umieszczono numery hipoteczne ${ }^{39}$.

Główną podstawę opracowania mapy Warszawy z drugiej połowy XVIII w.

\footnotetext{
$\overline{{ }^{36} \text { Atlas historyczny Warszawy, s. } 14 .}$

${ }^{37}$ Tamże, s. 26.

${ }^{38}$ Tamże, s. 56.

${ }^{39}$ Tamże, s. 74.
}

stanowią plany miasta przygotowane pod kierunkiem Williama Heerleina Lindleya w związku z budową wodociągów i kanalizacji ${ }^{40}$. Sa to pierwsze w pełni kartometryczne plany Warszawy oparte na osnowie geodezyjnej. Ich opracowanie poprzedzono pomiarami w terenie, w efekcie czego powstał plan niwelacyjny w skali 1:10 000 . Przygotowane zostały również plany ulic w skali 1:200, plany blokowe w skali 1:200 i 1:250 oraz plany sekcyjne przedmieść (1:500 i $1: 1000)$ i miasta $(1: 2500)$.

Na potrzeby projektu wykorzystywany jest głównie plan sekcyjny miasta w skali 1:2500, składający się z 26 arkuszy o wymiarach $94 \times 70 \mathrm{~cm}$ (ryc. 1). Opracowano go na podstawie planów blokowych i planów przedmieść. Przedstawia dokładną siatkę ulic i zabudowę miasta, a każda działka została opisana numerem porządkowym. Z powodu postępującej wówczas rusyfikacji napisy sporządzono jedynie w języku rosyjskim ${ }^{41}$. Wszystkie arkusze udostępnione zostały w wersji cyfrowej, za pośrednictwem serwisu internetowego Archiwum Państwowego w Warszawie ${ }^{42}$. Cały plan obejmuje ok. $88 \mathrm{~km}^{2}$, czyli 17 proc. obecnej powierzchni miasta ${ }^{43}$. Dla porównania, obszar wewnątrz wałów Lubomirskiego miał ok. $20 \mathrm{~km}^{2}$, czyli jedynie 3 proc. zasięgu miasta w XXI w. (ryc. 1).

\section{Przykłady wyzwań w integracji źródeł pisanych i kartograficznych}

W rekonstruowaniu przestrzeni miejskiej Warszawy końca XVIII w. wykorzystywane są metody pracy geografów historycznych i kartografów. Dotyczy to przede wszystkim zastosowania retrogresji, która pozwala wnioskować na podstawie źródeł późniejszych o stanie rozwoju przestrzeni

\footnotetext{
${ }^{40}$ R. Żelichowski, P.E. Weszpiński, William Heerlein Lindley. Plan Warszawy 1912. Plan niwelacyjny miasta Warszawy. Zdjęcie pod kierunkiem Głównego Inżyniera W.H. Lindleya, Warszawa 2016.

${ }^{41}$ Tamże, S. 187.

${ }^{42}$ Plany Lindleyów, „Archiwum Państwowe w Warszawie” (www.warszawa. ap.gov.pl/indley/skorowidz.html, dostęp: 30 maja 2019).

${ }^{43}$ Statystyki, „Miasto Stołeczne Warszawa" (https://www.um.warszawa.pl/ warszawa-w-liczbach/statystyki, dostęp: 30 sierpnia 2019).
} 
miejskiej w okresie wcześniejszym. Metodę odtwarzania historycznej topografii (method of recreating historical topography) opisała m.in. Marjana Dołynśka, posiłkując się przykładem Lwowa ${ }^{44}$. Warto również wspomnieć o geomatycznej metodzie wspomagania badań ${ }^{45}$, której procedury choćby wizualne czy statystyczne przetwarzanie danych i obrazu - pozwalają na usprawnienie metody retrogresji.

Należy jednak pamiętać, że każde miasto i źródło (szczególnie pisane) ma swoją specyfikę. Z tego względu w przypadku każdego miasta konieczne jest wypracowanie właściwej metody badawczej. Poniżej omówimy na wybranych przykładach pierwsze wnioski $\mathrm{z}$ integracji warszawskich źródeł pisanych i kartograficznych.

Pierwsze trudności pojawiły się podczas kalibracji planów Lindleyów. Zniszczenia z okresu drugiej wojny światowej spowodowały nieodwracalne zmiany w przestrzeni miejskiej (ryc. 2), dlatego też arkusze skalibrowano w oparciu o budynki nienaruszone w ciagu ostatnich stu lat (m.in. kościoły i pałace). By kalibracja została przeprowadzona jak najdokładniej, pod uwagę wzięto również obecny rozkład działek ewidencyjnych. Wstępne rozpoznanie wykazało, że przebieg granic części z nich nie uległ zmianie, chociaż mogłoby się tak wydawać, gdyby wziąć pod uwagę jedynie zabudowę analizowanego obszaru.

Do kalibracji wykorzystano dane z EGiB dostępne w formie Web Map Service ${ }^{46}$, a także bazę danych z działkami ewidencyjnymi LPIS dostępną poprzez wtyczkę do programu QGIS ${ }^{47}$. Obecnie wtyczka ta nie jest już rozwijana, a w grudniu $2018 \mathrm{r}$. zastąpiono ją wtyczką o nazwie Wyszukiwarka dziatek ewidencyjnych (ULDK $G U G i K)$. W roli podkładu wykorzystano mapę z „Open Street Map”48, również dostępną w oprogramowaniu QGIS w formie wtyczki.

Porównanie danych z EGiB z planem Lindleyów pozwoliło zidentyfikować w obu źródłach działki niezmienione lub takie, które jedynie podzielono. Przypadki tego rodzaju można odnaleźć na terenie współczesnych dzielnic Śródmieście Północne i Śródmieście Południowe. Precyzyjna i wiarygodna lokalizacja wierzchołków
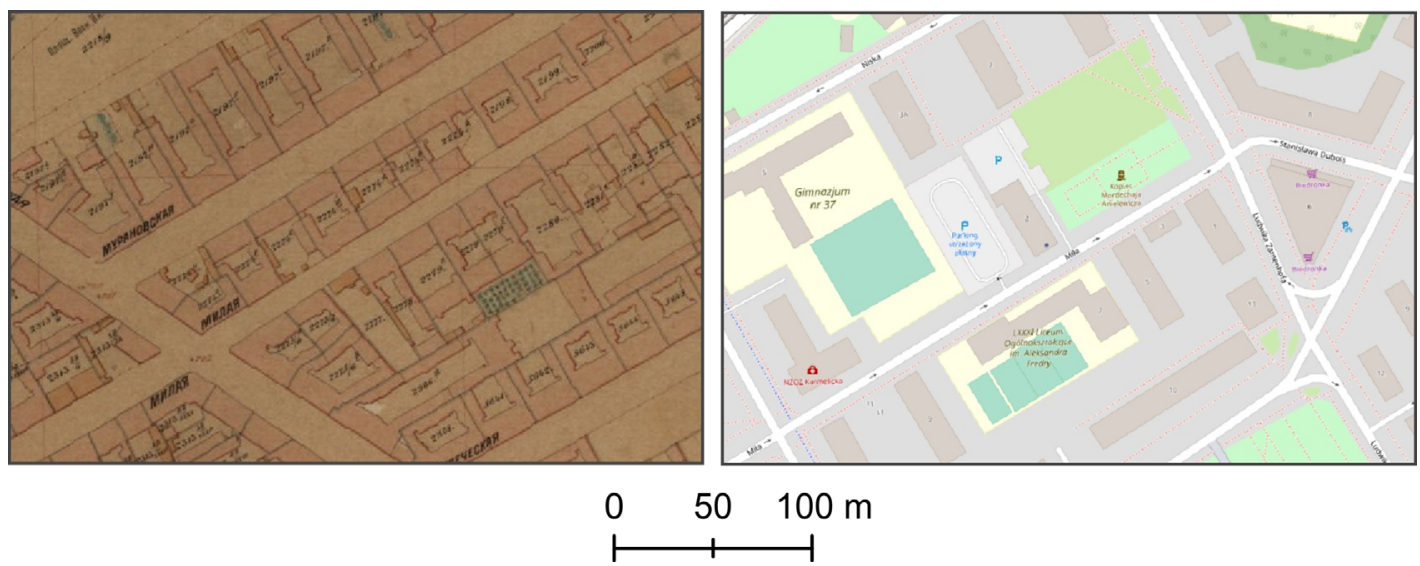

Ryc. 2. Okolica współczesnej ulicy Karmelickiej na planie Lindleyów (1) i Open Street Map (dalej: 0SM) (2). Źródto: oprac. własne na podkładzie planu Lindleyów w skali 1:2500 (zmniejszenie 1:2) i OSM

\footnotetext{
${ }^{44} \mathrm{M}$. Dolynska, Some principles of interdisciplinary investigation for recreating the historical topography of urban spaces, „Studia Geohistorica”, 6 , 2018, s. 169-184.

${ }^{45}$ Z. Koziet, Concerning the need for development of the geomatic research method, , Geodezja i Kartografia”, 66 (3), 1997, s. 217-224.
}

\footnotetext{
${ }^{46}$ Usługi przeglądania WMS i WMTS, „Geoportal” (www.geoportal.gov.pl/ uslugi/usluga-przegladania-wms, dostęp: 30 maja 2019).

${ }^{47}$ Wyszukiwarka LPIS, „GIS Support” (www.gis-support.pl/wtyczka-wyszukiwarka-Ipis, dostęp: 30 maja 2019).

48 „Open Street Map" (https://www.openstreetmap.org, dostęp: 30 maja 2019).
} 

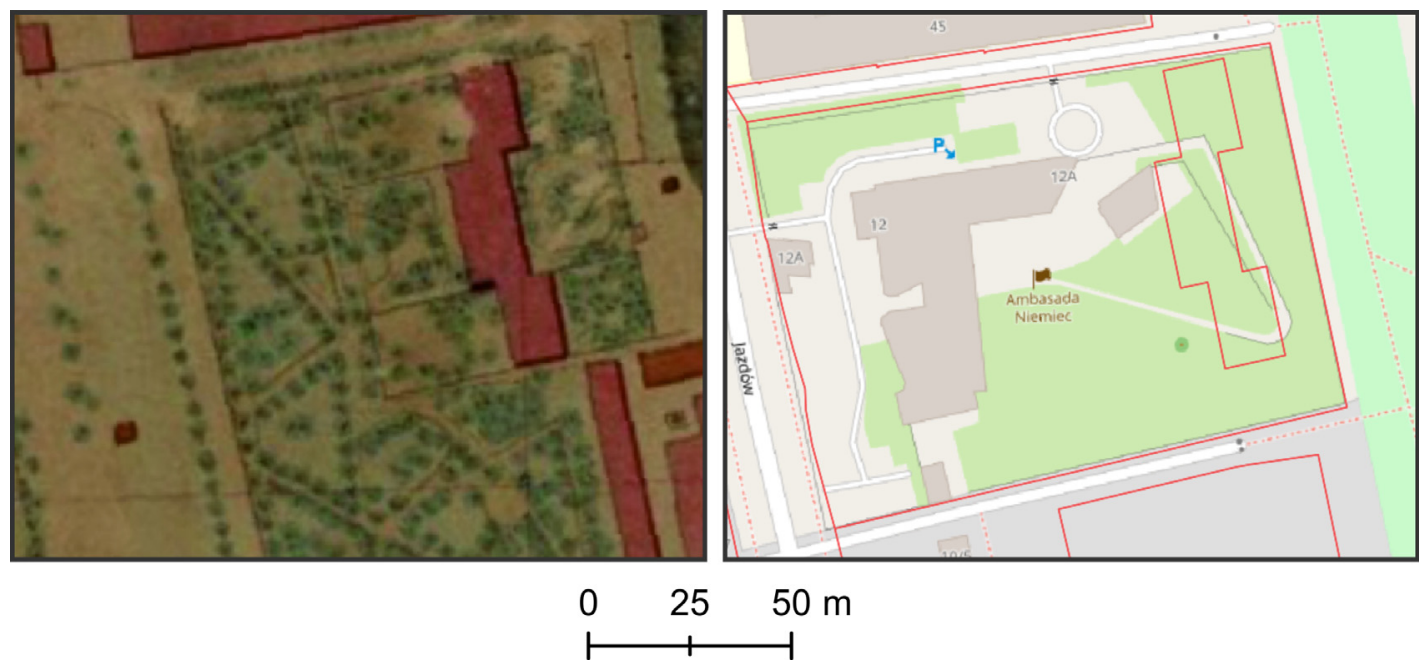

Ryc. 3. Porównanie obszaru przy wspótczesnej ul. Jazdów 12 na planie Lindleyów i działkach z EGiB (OSM w podkładzie). Źródto: oprac. własne na podkładzie planu Lindleyów w skali 1:2500, EGiB i OSM

działek pozwoliła na wykorzystanie ich do kalibracji map, a tym samym zwiększenie dokładności georeferencji na obszarach, gdzie niemożliwe było wybranie innych punktów kontrolnych. Przykładem może być tu obecny obszar ambasady Niemiec przy ul. Jazdów 12 (ryc. 3). Budynek znajdujący się na tym terenie przed pierwszą wojną światową uległ zniszczeniu, ale w bazie EGiB widnieje działka wskazująca jego dokładne położenie. Umożliwiło to postawienie punktu kontrolnego do georeferencji w jednym z narożników budynku. Kalibrację ułatwiło również to, że plan był użytkowany, a przez to aktualizowany. Tę dodatkową treść nanoszono kolorem czerwonym. Paweł E. Weszpiński wymienia jako przykłady Muzeum Narodowe oraz przebieg linii kolei średnicowej ${ }^{49}$.

Ze względu na szczegółowość źródeł oraz niską trwałość zabudowy drewnianej za punkt odniesienia przyjęto w projekcie działki, a nie budynki. Głównym wyzwaniem jest połączenie danych ze źródeł pisanych i kartograficznych. Informacje pozyskane ze źródeł miejskich wprowadzono do bazy danych, która w połączeniu z mapa wektorową (poprzez numer hipoteczny działki) pozwala na przeprowadzenie analiz przestrzennych dotyczących m.in. rodzaju zabudowy i własności (tab. 1).

W niespodziewanie dużej liczbie przeanalizowanych do tej pory przypadków opis działki z końca XVIII w. zgadza się z jej lokalizacją na planie Lindleyów. $\mathrm{Nu}$ meracja części działek, a także przebieg ich granic bywają jednak nieczytelne. Wynika to z niewystarczającej rozdzielczości wykorzystywanych skanów oraz stanu oryginałów.

Do tej pory zidentyfikowano dwa powtarzające się problemy - zmianę numeru działki oraz trudność we wskazaniu przebiegu granicy pomiędzy działkami w 1790 r. Z problemem pierwszym mamy do czynienia, gdy opis działki w źródle pisanym zgadza się z jej lokalizacją względem innych działek na planie, ale maja one inne numery. Przykładem może być pokarmelicki kościół Wniebowzięcia Najświętszej Maryi Panny i św. Józefa Oblubieńca przy ulicy Krakowskie Przedmieście. Wybudowano go w XVII w. i nie uległ zniszczeniu w trakcie drugiej wojny

${ }^{49}$ R. Żelichowski, P.E. Weszpiński, William Heerlein Lindley, s. 188. 
Tabela 1. Przykład danych ze spisu z 1784 r.

\begin{tabular}{|c|c|c|c|c|c|}
\hline Nr działki & Nazwa ulicy & Budynek & Rodzaj zabudowy & Rodzaj własności & Właściciel \\
\hline 386 & $\begin{array}{l}\text { Krakowskie } \\
\text { Przedmieście }\end{array}$ & kamienica & murowana & kościelna & ks. karmelici bosi \\
\hline 387 & $\begin{array}{l}\text { Krakowskie } \\
\text { Przedmieście }\end{array}$ & pałac & murowana & prywatna & ks. Karol Radziwiłł \\
\hline 388 & $\begin{array}{l}\text { Krakowskie } \\
\text { Przedmieście }\end{array}$ & pałac & murowana & prywatna & $\begin{array}{l}\text { ks. Izabela } \\
\text { Lubomirska }\end{array}$ \\
\hline 389 & $\begin{array}{l}\text { Krakowskie } \\
\text { Przedmieście }\end{array}$ & kamienica & murowana & kościelna & panny wizytki \\
\hline 390 & $\begin{array}{l}\text { Krakowskie } \\
\text { Przedmieście }\end{array}$ & dworek & drewniana & kościelna & panny wizytki \\
\hline 391 & $\begin{array}{l}\text { Krakowskie } \\
\text { Przedmieście }\end{array}$ & kamienica & murowana & kościelna & panny wizytki \\
\hline 392 & $\begin{array}{l}\text { Krakowskie } \\
\text { Przedmieście }\end{array}$ & $\begin{array}{l}\text { lektykarnia, front } \\
\text { kościoła i cmentarza } \\
\text { panien wizytek }\end{array}$ & murowana & miejska & $\begin{array}{l}\text { Miasto Stara } \\
\text { Warszawa }\end{array}$ \\
\hline 393 & $\begin{array}{l}\text { Krakowskie } \\
\text { Przedmieście }\end{array}$ & pałac & murowana & prywatna & $\begin{array}{l}\text { Ludwik Tyszkiewicz } \\
\text { hetman polny } \\
\text { litewski }\end{array}$ \\
\hline 394 & $\begin{array}{l}\text { Krakowskie } \\
\text { Przedmieście }\end{array}$ & pałac & murowana & królewska & Korpus Kadetów \\
\hline 395 & $\begin{array}{l}\text { Krakowskie } \\
\text { Przedmieście }\end{array}$ & kamienica & murowana & kościelna & Szpital św. Rocha \\
\hline 396 & $\begin{array}{l}\text { Krakowskie } \\
\text { Przedmieście }\end{array}$ & kamienica & murowana & prywatna & $\begin{array}{l}\text { sukcesorzy } \\
\text { Kojtkowskich }\end{array}$ \\
\hline
\end{tabular}

Źródło: oprac. własne na podstawie: AGAD, WE, sygn. 29a, k. 23-24

światowej ${ }^{50}$. W spisie z 1784 r. działka, na której stoi, ma numer 385, a na planie Lindleyów - już 2667 (ryc. 4). Problem braku zgodności między źródłem pisanym i kartograficznym dotyczy większego odcinka ulicy Krakowskie Przedmieście - od ulicy Bednarskiej do Pałacu Namiestnikowskiego. Według źródła pisanego na obszarze tym powinny znajdować się działki o numerach od 371 do 385 , ale na mapie są one opisane numerami od 2667 do 2673.

Problem drugi - trudność we wskazaniu przebiegu granicy pomiędzy działkami pojawia się w przypadku, gdy w czasach

\footnotetext{
${ }^{50}$ Rejestr zabytków nieruchomych m.st. Warszawy, „Narodowy Instytut Dziedzictwa" (www.nid.pl/pl//nformacje_ogolne/Zabytki_w_Polsce/rejestr-zabytkow/Zestawienia-zabytkow-nieruchomych/MAZ-WAR-rej.pdf, dostęp: 30 maja 2019).
}

opracowywania mapy Lindleyów były one już połączone albo powiększone o nowe podnumery. Przykładem działek połączonych może być inny obszar przy ulicy Krakowskie Przedmieście, a dokładnie teren przy kościele klasztornym misjonarzy pw. św. Krzyża (ryc. 5).

Sytuacja odwrotna - gdy w czasie pomiędzy sporządzeniem spisu a opracowaniem planu działkę podzielono - jest o wiele mniej problematyczna. W opracowywanej bazie zamieszcza się wówczas rekordy dla każdej z działek z początku XX w. i odpowiednią wartość w kolumnie dotyczącej numeracji z $1784 \mathrm{r}$. 


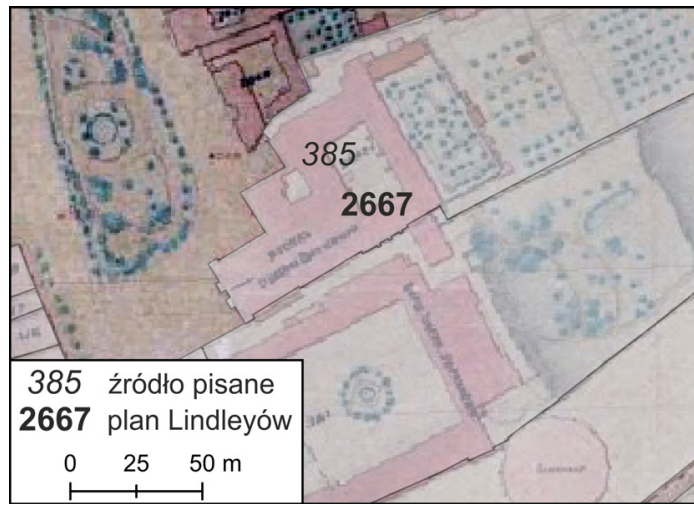

Ryc. 4. Działka z kościotem pokarmelickim - porównanie numeru ze spisu z 1784 r. z planem Lidleyów.

Źródto: oprac. własne na podkładzie planu Lindleyów w skali 1:2500

\section{Kartograficzna wizualizacja danych historycznych na przykładzie ulic Krakowskie Przedmieście i Grzybowskiej}

W poniższym fragmencie zaprezentowane będzie porównanie odcinków ulic Krakowskie Przedmieście i Grzybowskiej - a więc ścisłego centrum osiemnastowiecznej Warszawy i terenów podmiejskich. Analizę własności gruntów na terenie miasta umożliwiają źródła opisane $\mathrm{w}$ rozdziale trzecim. Na rycinie 6 przedstawiono rodzaje własności działek na wymienionych obszarach w oparciu o spis z 1784 r. Wyróżnione zostały: własność królewska, miejska (Starej Warszawy), kościelna oraz prywatna (mieszczańska i szlachecka). Należy podkreślić, że na podstawie rejestru z 1784 r. możliwe było określenie własności nieruchomości położonych na danej parceli, ale już nie jej przynależności własnościowej. $\mathrm{Na}$ Krakowskim Przedmieściu znajdowały się nieruchomości należące do króla Stanisława Augusta - pałac Korpusu Kadetów $(\text { nr } 394)^{51}$. Druga z własności królewskich to pałac elektora saskiego $(\mathrm{nr} 413)^{52}$.

${ }^{51}$ AGAD, WE, sygn. 29a, k. 24. Z powodu braku odpowiedniej karty w rejestrze z $1790 \mathrm{r}$. nie można określić własności działki.

52 Tamże, k. 24; AGAD, WE, sygn. 23, k. 362. Zarówno nieruchomość, jak i grunt były jego własnością.

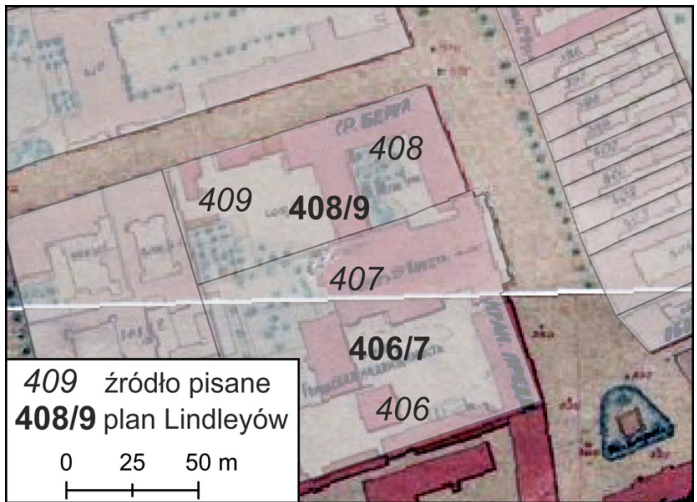

Ryc. 5. Działki w sąsiedztwie kościoła klasztornego misjonarzy pw. św. Krzyża - porównanie numeru ze spisu z 1784 r. z planem Lidleyów.

Żródto: oprac. własne na podkładzie planu Lindleyów w skali $1: 2500$
Na działce nr 392 znajdowała się należąca do Starej Warszawy lektykarnia, jak również front kościoła i cmentarza należącego do wizytek. Na terenie tym leżało też kilka nieruchomości będących własnością magnatów, tj. pałac hetmana polnego litewskiego hr. Ludwika Tyszkiewicza (nr 393) i dwa pałace księżnej Izabeli Lubomirskiej, żony Stanisława Lubomirskiego, marszałka wielkiego koronnego (nr 388, 415) ${ }^{53}$. Właściciele nieruchomości znajdujących się przy ulicy Grzybowskiej wywodzili się natomiast ze stanów szlacheckiego i miejskiego.

Rycina 7 prezentuje typ zabudowy na analizowanych obszarach. Wyróżnione zostały budynki murowane i drewniane (w tym zabudowa określana jako mur pruski). Klasyfikacji dokonano w odniesieniu do budynku znajdującego się we frontowej części działki. $Z$ danych zawartych w rejestrze z $1784 \mathrm{r}$. wynika, że na terenie Starej Warszawy dominowała zabudowa murowana, a w sąsiadującej z nią jurydyce Grzybów - drewniana. Był to wynik świadomej polityki Komisji Brukowej i marszałka wielkiego koronnego, aby na terenie Starej Warszawy nie powstawały budynki drewniane, przy czym

${ }^{53}$ AGAD, WE, sygn. 29a, k. 23, 25. 


\section{Krakowskie Przedmieście}

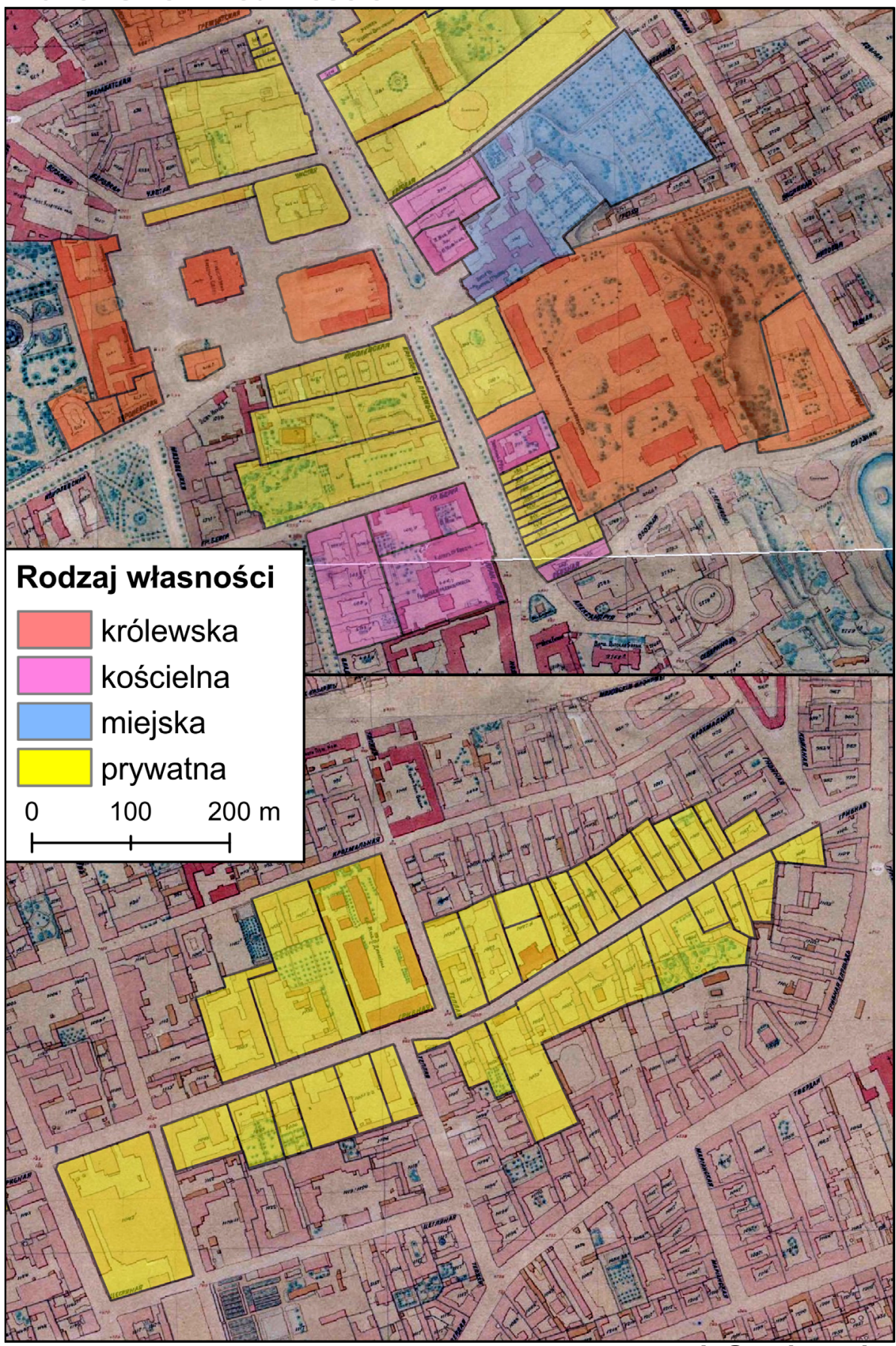

ul. Grzybowska

Ryc. 6. Porównanie rodzajów własności przy ulicach Krakowskie Przedmieście i Grzybowskiej. Źródto: oprac. własne na podkładzie planu Lindleyów w skali 1:2500 (zmniejszenie 1:3) 


\section{Krakowskie Przedmieście}

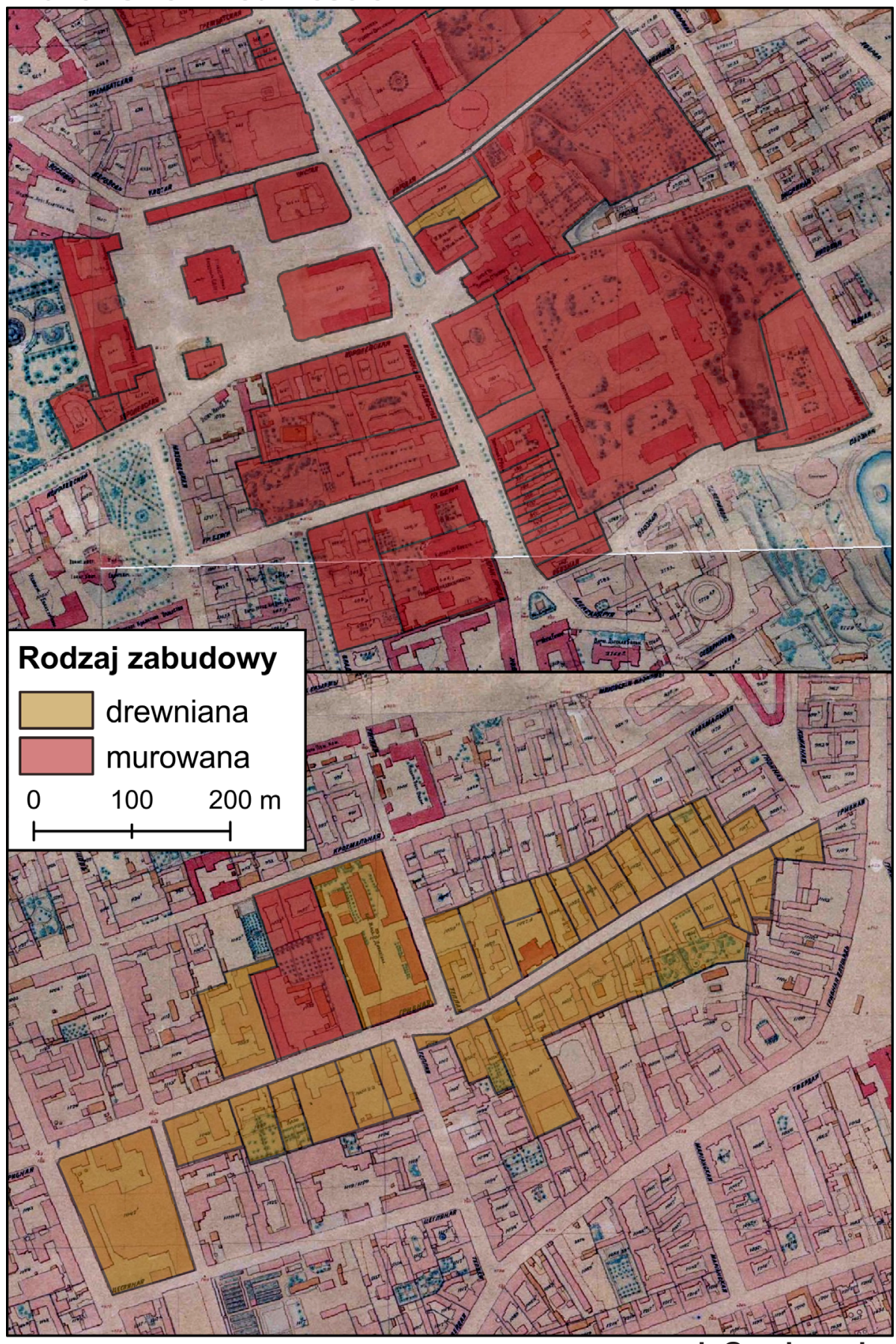

ul. Grzybowska

Ryc. 7. Porównanie typu zabudowy przy ulicach Krakowskie Przedmieście i Grzybowskiej.

Źródło: oprac. własne na podkładzie planu Lindleyów w skali 1:2500 (zmniejszenie 1:3) 
zakaz dotyczył w szczególności zabudowy z muru pruskiego ${ }^{54}$.

\section{Możliwości zastosowania wyników projektu i dalsze perspektywy badawcze}

Końcowym efektem realizacji projektu będzie mapa wektorowa Warszawy z XVIII w., na której zaznaczone zostaną najważniejsze obiekty, tj. kwartały zabudowy i ulice, a w zakresie uwarunkowanym dostępnością źródeł - poszczególne posesje, tereny zielone i obiekty wodne. Będzie to podstawa do prowadzenia dalszych badań nad podziałami administracyjnymi miasta w epoce przedrozbiorowej czy wyznaczeniem zasięgu okręgów parafialnych. Wykorzystanie oprogramowania GIS umożliwia zestawianie i porównywanie różnych planów, np. kształtu zabudowy, przebiegu ciągów komunikacyjnych czy położenia terenów zielonych.

$\mathrm{Z}$ mapy wektorowej będą też mogli skorzystać inni badacze dziejów Warszawy w epoce nowożytnej. Nanosząc na nią swoje dane źródłowe mające odniesienie przestrzenne, będą mogli prowadzić własne analizy i przygotowywać mapy tematyczne. Poza tym w ramach projektu przygotowana zostanie elektroniczna edycja źródłowa. Odejście od tradycyjnej papierowej formy uzasadnione jest typem źródeł, którymi są spisy ludności miasta. Przygotowanie edycji źródeł za pomocą dedykowanej aplikacji indeksującej umożliwi udostępnienie ich odbiorcom w całości, w postaci rękopisów. Planowane jest również udostępnienie opracowywanej przestrzennej bazy danych - zarówno w postaci plików, jak i geoportalu.

Wyniki prezentowanego projektu mają potencjał do wykorzystania $\mathrm{w}$ innych dziedzinach. Historycy sztuki będą mogli posłużyć się geoportalem w promocji dziedzictwa, np. poprzez zwiększenie potencjału kulturowego przestrzeni czy popularyzację historycznych form zagospodarowania przestrzeni. Zgromadzone dane mogą się również przydać specjalistom z zakresu gospodarki przestrzennej, którym zweryfikowany materiał źródłowy umożliwi podejmowanie uzasadnionych decyzji dotyczących zachowania przestrzeni historycznych.

Precyzyjne dopasowanie działek ze źródeł, które dzieli ponad sto lat, wymaga zgłębienia ówczesnej legislacji. Konieczna będzie również weryfikacja przebiegu granic części z nich w oparciu o opracowania kartograficzne w większej skali (np. plany blokowe w skali 1:200 i 1:250), które wraz z wykorzystywanym planem składają się na dziedzictwo kartograficzne Lindleyów ${ }^{55}$.

Opracowywaną bazę można będzie rozszerzać o inne dane mające odniesienie przestrzenne, np. pochodzace $\mathrm{z}$ protokołów konsensów ekonomii miasta Starej Warszawy z lat 1776-1796. Planowane jest również przygotowanie edycji wybranych źródeł miejskich przy użyciu aplikacji indeksującej. Wybrane treści źródła (w tym przypadku numer działki) zostaną przeniesione do bazy danych jako hasła indeksowe i połączone z mapą. Możliwe będzie dzięki temu wyświetlenie skanu źródła po wybraniu konkretnej działki na cyfrowym planie miasta.

\section{Podsumowanie}

Dotychczasowe badania nad nowożytna Warszawą nie wykorzystywały wszystkich informacji zawartych w źródłach pisanych i kartograficznych, ponieważ brakowało narzędzi niezbędnych do ich analizy. Kartograficzna wizualizacja historycznych danych spisowych pozwoli uchwycić zjawiska społeczne z nowej perspektywy, a przez to wzbogacona zostanie wiedza na temat miasta i jego mieszkańców w XVIII w. Przeprowadzenie analiz odnoszących się do Warszawy będzie istotnym wkładem w badania nad społeczeństwem miejskim w okresie przedrozbiorowym.

\footnotetext{
${ }^{55}$ R. Żelichowski, P.E. Weszpiński, William Heerlein Lindley, s. 165 


\section{Bibliografia}

Atlas historyczny Warszawy. Wybrane źródta kartograficzne, red. A. Jankiewicz, Warszawa 1999.

Bartoszewicz A., Warta-spoteczeństwo miasta w II potowie XV i na początku XVI wieku, Warszawa 1997.

Berdecka A., Turnau I., Zycie codzienne w Warszawie okresu Oświecenia, Warszawa 1969.

Boguska M., Kwiatkowska M.I., Kwiatkowski M., Tomkiewicz W., Zahorski A., Warszawa w latach 1526-1795, w: Dzieje Warszawy, t. 2, red. S. Kieniewicz, Warszawa 1984, s. 300.

Chodějovská E., Gearty S., Stracke D., The „digital turn" of the European Historic Towns Atlas: comparing solutions for digital atlas production and online presentation, „Città e Storia”, 10 (1), 2015, s. 89-121.

Czaja R., Historical Atlas of Polish Towns - between source edition and the cartographic presentation of research on the history of towns, "Studia Geohistorica”, 6, 2018, s. 80-90.

Czaja R., Socjotopografia miasta Elblaga $w$ średniowieczu, Toruń 1992.

„DECIMA” (www.decima-map.net, dostęp: 30 maja 2019).

Dolynska M., Some principles of interdisciplinary investigation for recreating the historical topography of urban spaces, „Studia Geohistorica”, 6, 2018, s. 169-184.

Els „Quarterons Garriga i Roca”. Barcelona, darrera mirada. Una ciutat de mitjan segle XIX a punt de canviar per sempre, „Ajuntament de Barcelona” (www. darreramirada.ajuntament.barcelona.cat, dostęp: 30 maja 2019).

Goliński M., Socjotopografia późnośredniowiecznego Wroctawia (przestrzeń - podatnicy - rzemiosto), Wrocław 1997.

Grochulska B., Problem wzrostu ludności Warszawy $w$ drugiej potowie XVIII wieku, „Rocznik Warszawski”, 7, 1966, s. 182-187.

Grochulska B., Warszawa na mapie Polski stanistawowskiej. Podstawy gospodarcze rozwoju miasta, Warszawa 1980.

Hentschel W., Die sächsische Baukunst des 18. Jahrbunderts in Polen, Berlin 1967.

Herbst S., Ulica Marszatkowska, Warszawa 1949.

Kłosek-Kozłowska D., O wartościach przestrzennych Osi Saskiej Warszawy, „Kwartalnik Architektury i Urbanistyki”, 62 (3), 2017, s. 5-42.

Kosacka D., Pótnocna Warszawa w XVIII wieku, Warszawa 1970.

Koziel Z., Concerning the need for development of the geomatic research method, „Geodezja i Kartografia”, 66 (3), 1997, s. 217-224.

Kriegseisen W., Ewangelicy warszawscy w dobie Sejmu Czteroletniego. Miejsca zamieszkania, zawody, zamożność, w: Obecni... Karty z dziejów ewangelików warszawskich. Materiaty z sesji popularnonaukowej, [oprac. B. Rogalska, J. Wiśniewska], Warszawa 1992, s. 28-34.

Kuklo C., Rodzina w osiemnastowiecznej Warszawie, Białystok 1991.

Kultura artystyczna Warszawy XVII-XX w., red. A. Pieńkos, Z. Michalczyk, M. Wardzyński, Warszawa 2010.

"Layers of London” (www.layersoflondon.org, dostęp: 30 maja 2019).

Lelo K., A GIS approach to urban history. Rome in the $18^{\text {th }}$ century, „ISPRS International Journal of Geo-Information”, 3 (4), 2014, s. 1293-1316.

Lloyd C.D., Gregory I.N., Shuttleworth I.G., Lilley K.D., Exploring change in urban areas using GIS. Data sources, linkages and problems, „Annals of GIS”, 18 (1), 2012, s. 71-80.

Mikulski K., Przestrzeń i spoteczeństwo Torunia od końca XIV do początku XVIII wieku, Toruń 1999.

Mrozowski K., Przestrzeń i obywatele Starej Warszawy od schytku XVw. do 1569 roku, Warszawa 2017, mps pracy doktorskiej, Biblioteka Instytutu Historii Uniwersytetu Warszawskiego.

Obecni... Karty z dziejów ewangelików warszawskich. Materiaty z sesji popularnonaukowej, [oprac. B. Rogalska, J. Wiśniewska], Warszawa 1992.

„Open Street Map” (https://www.openstreetmap.org, dostęp: 30 maja 2019).

Plany Lindleyów, „Archiwum Państwowe w Warszawie” (www.warszawa.ap.gov.pl/lindley/skorowidz.html, dostęp: 30 maja 2019).

Rejestr warszawskiej ludności wyznania ewangelicko-augsburskiego z 1791 roku, oprac. indeksu osób M. Kubaś, Warszawa 1996.

Rejestr zabytków nieruchomych m.st. Warszawy, „Narodowy Instytut Dziedzictwa” (www.nid.pl/pl/Informacje_ogolne/Zabytki_w_Polsce/rejestr-zabytkow/ zestawienia-zabytkow-nieruchomych/MAZ-WAR-rej.pdf, dostęp: 30 maja 2019).

Rutkowski H., Dawna kartografia Warszawy, „Rocznik Warszawski”, 32, 2004, s. 95-98.

Serwisy Mapowe, „Miasto Stołeczne Warszawa” (www. mapa.um.warszawa.pl, dostęp: 30 maja 2019).

Sito J., „ „Od czasów Augustów szczególniej liczba niemieckich artystów i rzemieślników w Warszawie wzrosta...". O roli nacji niemieckiej w przedsięwzięciach budowlano-artystycznych Warszawy okresu saskiego, w: Kultura artystyczna Warszawy XVII-XX w., red. A. Pieńkos, Z. Michalczyk, M. Wardzyński, Warszawa 2010, s. 159-171.

Sowina U., Sieradz. Uktad przestrzenny i spoteczeństwo miasta $w X V-X V I w$. Warszawa-Sieradz 1991.

Statystyki, „Miasto Stołeczne Warszawa” (https://www. um.warszawa.pl/warszawa-w-liczbach/statystyki, dostęp: 30 sierpnia 2019). 
Szaniawska W., Zmiany w rozplanowaniu i zabudowie Krakowskiego Przedmieścia do 1733 r., „Biuletyn Historii Sztuki”, 29, 1967, s. 285-315.

Szwankowska H., Drewniana zabudowa mieszkaniowa Warszawy Oświecenia, w: Warszawa XVIII wieku, z. 1: Studia warszawskie, red. J. Kowecki, Warszawa 1971, s. 191-228.

Szymkiewicz S., Warszawa na przetomie XVIII i XIX w. w świetle pomiarów i spisów, Warszawa 1959.

Ustugi przegladania WMS $i$ WMTS, „Geoportal” (www.geoportal.gov.pl/uslugi/usluga-przegladania-wms, dostęp: 30 maja 2019).

Warszawa XVIII wieku, z. 1: Studia warszawskie, red. J. Kowecki, Warszawa 1971.

Wiesiołowski J., Socjotopografia późnośredniowiecznego Poznania, Poznań 1997.

Wnęk K., Wtasność nieruchomości w Krakowie w potowie XIX w. Studia nad statym katastrem galicyjskim, Kraków 2011.
Wyrobisz A., Nazwy placów, ulic i dzielnic w miastach polskich: nośniki informacji - źródta historyczne zabytki kultury, „Przegląd Historyczny”, 90, 1999, s. 511-523.

Wyszukiwarka LPIS, „GIS Support” (www.gis-support.pl/wtyczka-wyszukiwarka-lpis, dostęp: 30 maja 2019).

ZielińskaT., Szlacheccy wtaściciele nieruchomości w miastach XVIII w., Warszawa-Łódź 1987.

Zwierz K., Miasto sejmowe Warszawa-polityczne uwarunkowania rozwoju miasta 1570-1655, Warszawa 2019, mps pracy doktorskiej, Biblioteka Instytutu Historii im. Tadeusza Manteuffla Polskiej Akademii Nauk.

Żelichowski R., Weszpiński P.E., William Heerlein Lindley. Plan Warszawy 1912. Plan niwelacyjny miasta Warszawy. Zdjęcie pod kierunkiem Gtównego Inżyiera W.H. Lindleya, Warszawa 2016.

\section{Challenges of Integration of Cartographic with Text Sources on the Example of Warsaw in the Eighteenth Century}

\section{Summary}

The use of Geographic Information Systems in the work of historians (HGIS) create new opportunities and perspectives for research into the transformation of urban space from the beginning of the functioning of cities to modern times. The domestic and foreign research projects currently being implemented make use of these solutions to varying degrees. Not in all cases maps developed using GIS tools are made available in a digital version. Undoubtedly, the standards and directions in this type of research are set by the International Commission for the History of Towns, which officially adopted the digital strategy in 2014.

On Polish ground, research teams working on the next volumes in the "Atlas of Polish Cities History" series, prepare them both in paper and digital versions. In the case of Warsaw, research in this area is still an important research postulate.

It should be emphasized that the preserved set of written sources (including censuses of residents and real estates from the 1790s) and cartographic plans (including plans of Warsaw prepared under the supervision of William Heerlein Lindley from the end of the $19^{\text {th }} \mathrm{c}$.) allows for a thorough diagnosis of the city's spatial development throughout this period and an indication of significant demographic trends. This article presents the preliminary results of the work undertaken by the team on the integration of data from the two types of sources mentioned above. The following issues are discussed: calibration of the Lindley's plan, records of city plots, establishment of boundaries between neighbouring plots. Visualizations of the types of ownership and building materials are prepared on the example of two areas differing in character: Krakowskie Przedmieście Street (the strict centre of the $18^{\text {th }}$-century city) and Grzybowska Street (suburban areas). These works constitute the basis for developing a research method necessary to prepare a Warsaw base map in the $18^{\text {th }}$ century. 
dr Marta Kuc-Czerep - adiunkt w Zakładzie Studiów Nowożytnych Instytutu Historii im. Tadeusza Manteuffla Polskiej Akademii Nauk. Specjalizuje się w historii miast w epoce nowożytnej

(m_kuc@02.pl)

mgr Katarzyna Słomska - asystent w Zakładzie Atlasu Historycznego w Instytucie Historii im. Tadeusza Manteuffla Polskiej Akademii Nauk. Absolwentka geografii ze specjalnością kartografia. Na Wydziale Geografii i Studiów Regionalnych Uniwersytetu Warszawskiego przygotowuje pracę doktorską nt. użyteczności map ze względu na medium publikacji

(k.slomska@uw.edu.pl)

Marta Kuc-Czerep, PhD - assistant professor at the Department of Modern History of the Tadeusz Manteuffel Institute of History, Polish Academy of Sciences. She specializes in the history of cities in the modern era (m_kuc@02.pl)

Katarzyna Stomska, MA - research assistant of the Department of Historical Atlas at the Tadeusz Manteuffel Institute of History, Polish Academy of Sciences. She graduated in geography with a specialization in cartography. Currently, she has been working on doctoral dissertation on the usability of maps in relation to the medium of publication at the Faculty of Geography and Regional Studies at the University of Warsaw

(k.slomska@uw.edu.pl) 